\title{
Use of high-rise structures for sustainable tourism
}

\author{
Tatiana Ya. Vavilova ${ }^{1 *}$, and Efim G. Vyshkin ${ }^{1}$ \\ ${ }^{1}$ Samara State Technical University, 194, Molodogvardeyskaya St., 443001, Samara, Russia
}

\begin{abstract}
The paper deals with such issues as formation and development of the infrastructure of objects for serving tourists in urban environment and specially protected natural areas with particular focus on open tower structures - a type of object which is so popular in Russia. The authors systematize international experience of integrating watchtowers in natural and anthropogenic environment as well as specific features of their modern architectural solutions. A number of examples are given. Summing up the results of the analysis we have come to conclusion that in the field of tourism the most promising tendency in functional use of vertical structures is the demonstration of cultural and natural attractions. It is also noted that in national and natural parks objects of the tower type can be built for other purposes, e.g. for conducting research, monitoring weather conditions and emergency situations. It is shown that the development of infrastructure of high-rise buildings for educational tourism contributes to sustainable development of territories and settlements.
\end{abstract}

\section{Introduction}

The Russian Federation has high potential for developing domestic and international tourism [1]. Throughout the country there are more than 40 historical settlements of federal importance, objects of the world cultural and natural heritage, more than 13070 specially protected natural areas (SPNAs) of federal, regional and local importance. The increase in the number of foreign tourists visiting our country is confirmed by selective official data of the Federal State Statistics Service. The overall number of inbound tourists per year reached about 26.852 million in 2015. This exceeds the ratio of 2014 for more than 1.4 million. It allows making a conclusion that there is some growth of attractiveness of tourism as a sphere of entrepreneurial activity.

In many countries educational tourism is considered to be one of the priority sectors of the economy. In particular, all business activities in SPNAs can be developed on its basis $[2,3]$. The major obstacle to the improvement of tourism service in Russia is the poor quality of infrastructure providing services for tourists [4]. According to the Department of State Policy and Environmental Regulation of Ministry of Natural Resources (2013) up to $75 \%$ of the NP potential is used inefficiently. The types and number of buildings and small architectural forms do not currently meet modern requirements neither in organization of

* Corresponding author: vatatyan63@yandex.ru 
scientific research, nor in the variety of services and level of comfort. Moreover, the condition of engineering structures, branching and methods of improving routes and places of visitors' concentration don't allow minimizing environmental impact under increasing recreational pressure [5-7].

In the era of sustainable development of natural and urbanized areas the erection of observation towers (watchtowers) and other high-rise structures has become the main trend in improving the quality of educational touristic infrastructure. Their design and construction, which can be called one of the drivers to increase popularity of guided tours, are most widely-spread in Europe, China and the United States. Let us consider the possibility of using tower structures for developing tourism in the Russian Federation.

\section{Materials and Methods}

\subsection{Scientific basis for developing educational touristic infrastructure and constructing open high-rise structures}

In the contemporary history of Russia at the time when market relations have started to form, the most attention to science-based development of tourism objects infrastructure has been paid by economists and architects.

The economic value of tourism in Russia and the strategy of its development was considered in the thesis works by D. A. Kovalev (2006), Yu. V. Chernyavsky (2011) and M. V. Vinogradova (2013), as well as in the thesis work by the specialist in economic geography M. S. Bezuglova (2007). The contribution of the tourism sector to sustainable development of regions was studied in the papers by R. V. Hachmamuk (2004), L. V. Vasilyeva (2006), S. A. Sevastyanova (2006), K. V. Maslennikova (2007), E. M. Maksarova (2009), O. A. Bunakov (2011), E. G. Kiyakbaeva (2015), D. S. Khasova (2015) and others. The issue of objects' infrastructure development was touched upon by A. S. Levizova (2008), A. V. Kuchumov (2011), D. F. Vasilikha (2012), O. B. Evreinov (2012), V. E. Kotelnikova (2014), etc.

Urban and architectural-typological features of tourism objects became the subject of thesis studies by Yu. S. Fedorova (1998), V. A. Antyufeev (2007), N. F. Vdovin (2009), N. V. Morozova (2012), L. A. Fedotova (2013), O. A. Antyufeeva (2014), E. K. Bulatova (2014), A. N. Azizova-Poluektova (2015), A. F. Perova (2015), M. E. Pechenik (2016). Scientific background for the principles of spatial organization of the tourism objects network has been developed in a number of theses by foreign authors, for example, by A. Sh. Sultanalieva (1997) for Kyrgyzstan, by Zhu Binsy (2009) and Ven I (2009) for China.

It should be noted that developing the infrastructure of educational tourism in Russia is still associated with improving objects related to the tourists' accommodation (hotels, motels, campsites, etc.). However, buildings and structures on the routes that provide contemplation, identification and memorization of cultural or natural attractions have remained beyond designers and investors' vision for years [8, 9]. Among them there are information and visitor centers, observation towers and sightseeing platforms, small architectural forms and elements of branding. Meanwhile, these objects are designed to increase the effect of perception of the unique urban or natural environment, to enhance understanding of the aesthetic uniqueness of a particular area [10-12].

Modern tourism is an interdisciplinary phenomenon. International and Russian practice of its development is based on the integration of various production and service industries, aimed at meeting the leisure demands of people. It employs the theory of cluster development and the idea of forming an integrated system of objects and services. The key element of this system is destinations - territories possessing a certain potential for tourism 
development $[13,14]$. Cluster-destination approach allows taking into account the uneven distribution of tourism resources, specific character of the area climatic conditions, their cultural-historical and socio-economic characteristics. In this regard, improving the competitiveness of the tourism sector of the economy is associated with the creation of favorable investment climate for infrastructure formation. In the international theory and practice at the turn of the 20th and 21 st centuries, the issues of its development have become in the focus of interest $[15,16]$.

Probably one of the first attempts to achieve comprehensive understanding of architectural and design approaches to the development of touristic infrastructure has become a planning and design guidebook edited by M. Baud-Bovy, F. Lawson (the United States) and first presented in 1977. In its updated version (1998) the authors took into account environmental, social and economic aspects, actualizing sustainable development issues [17]. Then in 1999 the book about tower structures by J. Kleinmanns was published in Germany. The author noted that observation towers are mostly used for tourism. In addition, they can still be used to prevent fires, and to accommodate transmitting and receiving $\mathrm{TV}$ and radio systems. The author gave examples of multifunctional operation of observation tower structures, co-located with a restaurant and a mini-hotel. Besides, the types of structural schemes and building materials were systematized and the principles of ensuring personal safety of tourists were identified [18]. At present this book remains the only publication in which the typological features of open towers and tower structures with internal space were classified and analyzed.

Undoubtedly more recent investigations related to regulation of the architectural environment of touristic infrastructure objects are of great interest, for example, the U. S. Army Corps of Engineers (USA) and the Department of National Parks, Sport and Racing (Austria). They contain standards of spaces development for different types of recreational activities $[19,20]$.

\subsection{Review of traditions and modern experience in the design of open high- rise structures}

\subsection{Historical prototypes of modern observation towers}

Numerous observation structures and bell towers in fortresses and monasteries, dominants at city halls and towers for engineering purposes built in the 19th and 20th centuries can rightfully be considered as prototypes of modern observation towers. Many of these objects are actively used for sightseeing in many countries. The most vivid example is the Eiffel tower, its observation platforms are annually visited by millions of tourists.

In the 20th century in connection with the development of recreation and entertainment industry high-rise objects began to be built purposely. One of their functions was to regulate the recreational load on the system of nature conservation areas (figure 1).

The steel observation tower on the Hot Springs mountain (figure 1a) also used for wireless telegraph communication was built in the eponymous national park (Arkansas, the USA) in 1906. Its height is $50.3 \mathrm{~m}$. It is interesting to mention that since 1877 in the same place there had been a wooden dominant about $23 \mathrm{~m}$ high. In 1975, the metal tower in poor condition was demounted, but in 1983 and in its place a new building $65.8 \mathrm{~m}$ high was built. It was designed exclusively for tourism purposes [25]. 

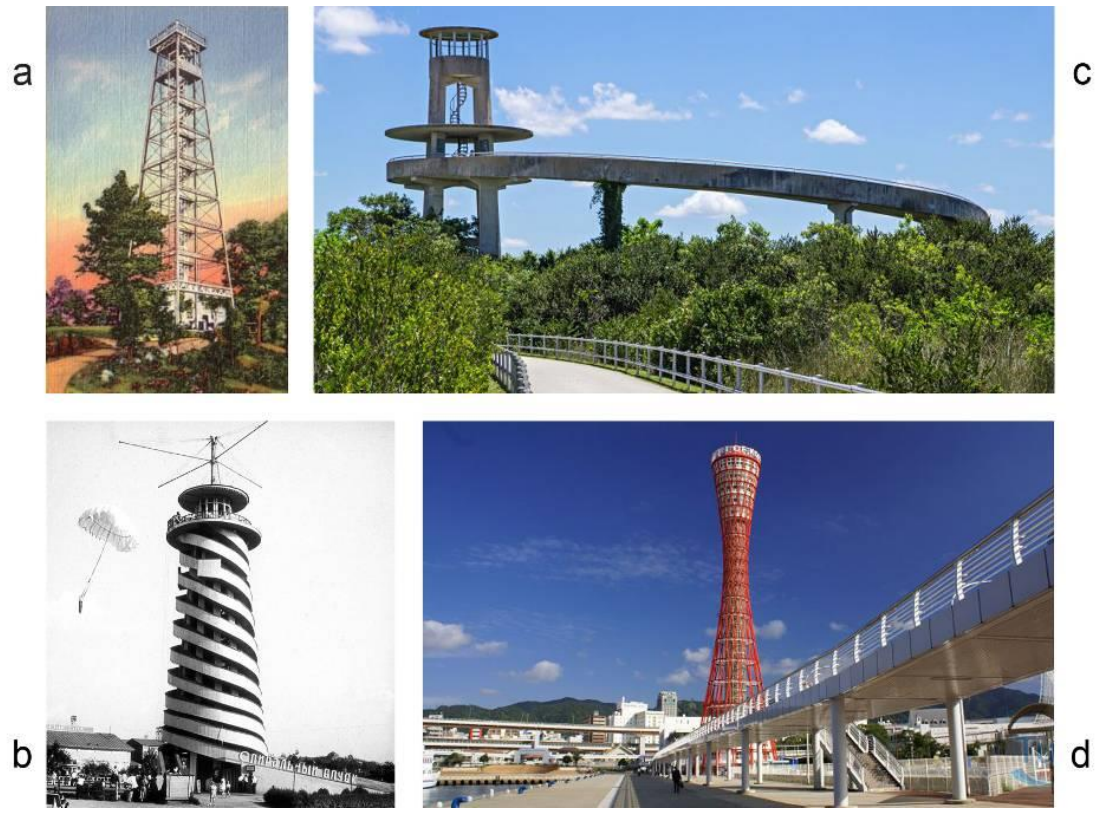

Fig. 1. Examples of tower structures of the 20th century:

a - national park Hot Springs, USA, the photo was taken in1932 [21], b - Central Park of Culture and Leisure named after Gorky, Moscow, USSR, the photo was taken in 1937 [22]; c - Shark Valley, Miami, United States [23]; d - Kobe, Japan [24]

Wooden tower structures approximately $30 \mathrm{~m}$ high, built in the parks of the Soviet Union in 1930s, are of particular interest (figure 1b). They were used as entertainment extreme rides for parachute jumping. Their spectacular appearance, that vaguely resembles the symbol of the revolutionary era - the Tatlin Tower, was conditioned by spirals of stair railings. In the upper part there was an observation platform.

The principle of the spiral ascent was used while erecting the tower in Shark Valley of Everglades National Park in Miami, USA (Figure 1c). Its observation platform, built in 1984 above the habitat of reptiles - crocodiles and turtles, is on the height of twenty meters. This also allows creating a panoramic view of the area. It should be particularly noted that there are no steps on the flat gradient, which is essential for disabled visitors [26].

In Japan the 90-meter hyperboloid tower in Kobe city built in 1963 has become such a unique object (Figure 1d). The designers surrounded the inner cylindrical core with the constructive system, which was invented by the great Russian engineer V. G. Shukhov and applied by him in the construction of the famous building in Moscow. The strength properties of the shell allow this Japanese construction to withstand seismic vibrations of great power. On the upper levels there are shops, cafes, and an observatory. One of the tiers of the service zone rotates and floor slabs have holes filled with break-resistant glass. All these details attract tourists from all over the world, and it is not surprising that every day the object is visited by 3 thousand tourists [24].

The second half of the 20th century was a period of conducting experiments. The profitability of constructing observation towers was proven. Here is just one example. Built in 1959, a small elevated observation platform in the Great Smoky Mountains of the National Park (the USA), which vaguely reminds the tower in Everglades park is annually visited by about 600 thousand tourists from April to November [27]. 


\subsubsection{Modern experience of designing and constructing touristic high-rise buildings}

In the 21 st century professional architects and designers have been actively involved in designing open high-rise buildings for tourism purposes. They have created objects that, from the very beginning, have played the role of "magnets" that attract tourists. This is of particular importance for developing tourism in the province. For example, the construction of an observation tower in the Latvian village of Shashkes located on the border with Lithuania and Belarus was planned in order to attract tourists [28].

Modern observation towers ceased to be the ordinary engineering structures long time ago. Unique technical and architectural solutions allow them to become city or area symbols, identifiers. This is most evidently seen in the tower construction in the urban environment (figure 2).

a

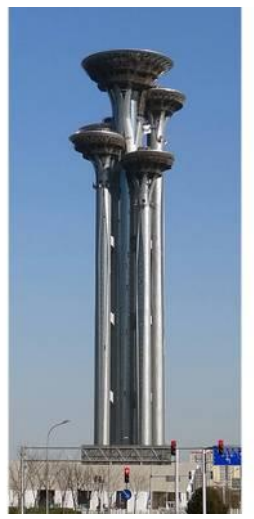

b

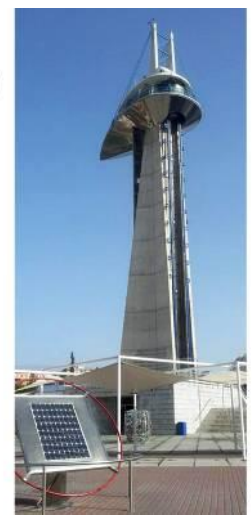

C

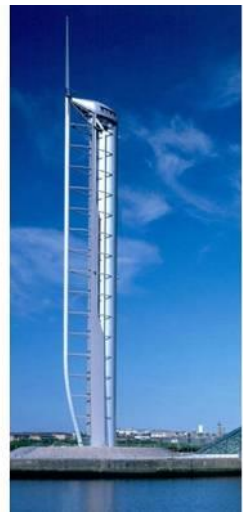

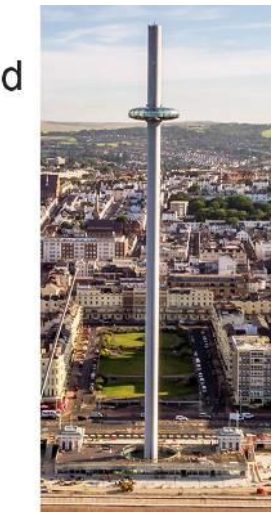

Fig. 2. Examples of observation towers located in the urban environment:

a - Beijing, China [29]; b - Madrid, Spain [30]; c - Glasgow, Scotland [31]; d - Brighton, England [32]

In most cases observation towers constructed in cities and suburbs, play the role of amusements. Going upstairs, staying on the sky deck and going downstairs are often enhanced by rotation of the platform (Düsseldorf, Singapore, Brighton, etc.). The height of such structures is taken considering the conditions of panoramic perception, and is limited mainly to the load-bearing capacity of structures and the necessity of taking into account wind pressure.

The highest contemporary observation tower with a rotating platform is British Airways i360 located above the beaches of Brighton (England). It was commissioned in 2016. The core reaches the height of nearly $162 \mathrm{~m}$ (Figure 2d). In the glass capsule up to 200 passengers can rise to the elevation of $138 \mathrm{~m}$ simultaneously. Technically and technologically advanced solution had been developed and implemented for 11 years. Project authors - architects of Marks Barfield Architects Bureau are famous for construction of the Millenium Observation Wheel (London Eye) [32].

In contrast to solutions suitable for the urban environment, objects for national and natural parks are maximally adapted to the landscape features of the area. Traditional materials aremainly used: concrete, metal, wood, glass, and their combinations. The degree of openness of structures may vary depending on the functional purpose. In composite solutions three main approaches can be traced - contextual (figure 3), accentual (figure 4) and contrasting (figure 5). 

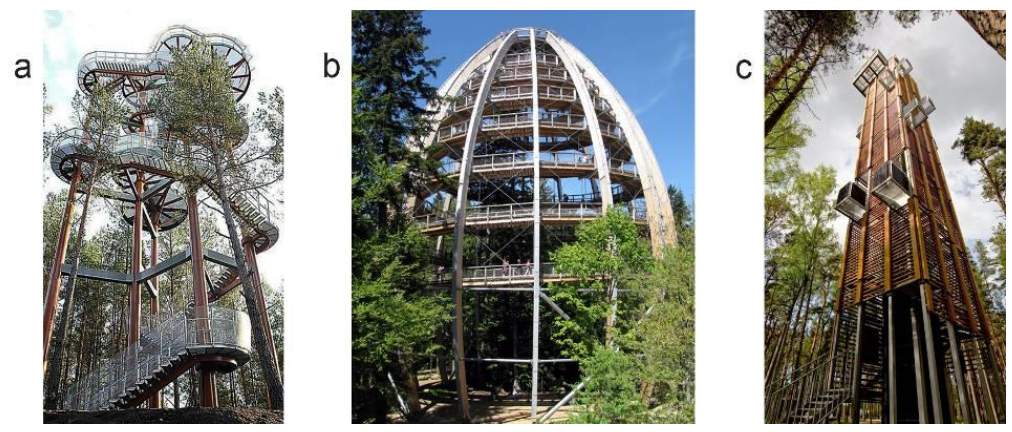

Fig. 3. Examples of the contextual approach to integration of observation towers in the natural environment: a - Lithuania [33]; b - Germany [34]; c - Latvia [35]
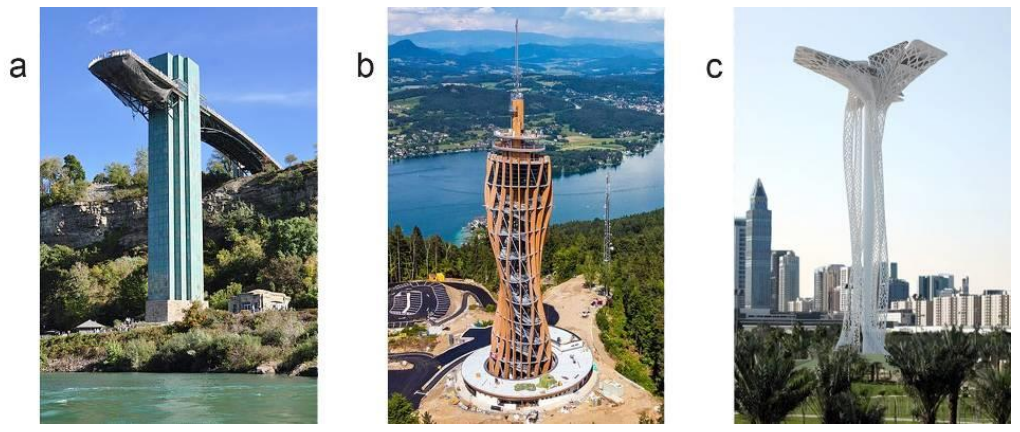

Fig. 4. Examples of the accentual approach to integration of observation towers in the natural / natural-anthropogenic environment : a - USA [36]; b - Austria [37]; c - United Arab Emirates [38]
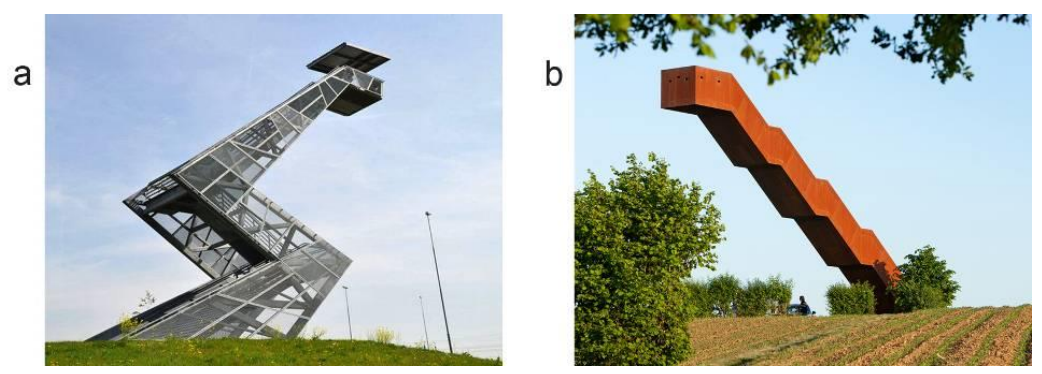

Fig. 5. Examples of the contrasting approach to integration of observation towers in the natural / natural-anthropogenic environment: a - Netherlands [39]; b - Belgium [40]

\section{Results and discussion}

Analysis of the theoretical base, historical and contemporary experience of design and construction of open structures of the tower type allows making a number of conclusions related to their use. Due to intensification of social processes, raising importance of ecological security on the international and national levels and increasing opportunities for introduction of scientific and technological innovations, the functions of observation towers can vary a lot, including multi-purpose towers. For example:

- in the natural and urban environment the most promising tendency in functional use of open high-rise objects is the demonstration of cultural and natural attractions; for the erection of these buildings in cities the areas of parks and garden squares adjacent to zones of cultural heritage objects' concentration can be used as well as special sites located within 
easy reach. In particular, it refers to the acquaintance with the monuments of the archaeological heritage;

- high-rise structures can serve as a kind of landmarks in space, which help tourists to orient on the routes;

- in national and natural parks the construction of tower-type objects on the sites of panoramic perception provides maximum aesthetic effect - the attractiveness of the landscape;

- towers tend to be like attractive "magnets", in the vicinity of which the tourist accommodation objects and rest stops, visitor centers, trade and service companies, in particular, objects of public catering, health care, equipment repair or transport can be build; this approach allows localizing the zone of increased recreational load in close proximity of towers;

- the use of high-rise dominants as structures to place engineering systems of alternative energy - solar and wind can reduce the consumption of non-renewable environmental resources and the ecological balance disruption;

- open high-rise structures can serve to shelter people during bad weather or when they observe objects of the natural world;

- observation towers, that rise predominant above trees, are located in the areas of improved radar systems; they are used for communication with groups or individual travelers and their movement control;

- high-rise dominants designed for conducting research (aero-labs), monitoring weather conditions and emergency situations can be erected in nature conservation areas;

- towers can also perform the traditional role of the water retaining construction, and become part of the reserve system for collecting rainwater for later use during dry periods.

Many of functions performed by towers contribute to adherence to the principle of comprehensiveness, which is considered a prerequisite for sustainable tourism development.

Perhaps, the most complicated problems include regulation of height, choice of composition and structural layout of these structures. Focusing on the principle of diversification, however, a number of corrective restrictions should be mentioned. They include, above all, the following:

- necessity of taking into account the statutory and regulatory requirements for organizing protected zones of cultural heritage objects with regard to their valuable status;

- compliance of the altitude dominate role with the category and zone mode of the nature conservation area;

- specificity of natural and climatic conditions;

- landscape and geological features of the area;

- technological base for construction, allowing to reduce environmental impact during the construction and operation of tower structures;

- tourists safety during the tour;

- possibility of meeting the needs of disabled categories of population.

\section{Conclusion}

The use of high-rise structures of open type for educational tourism purposes is one of the most controversial. On the one hand, the construction of high-rise dominants is constrained by the conservatism of tradition, and existing regulations concerning the development of the urban environment and nature conservation areas. On the other hand, observation towers give more opportunities to educate, to familiarize tourists with unique cultural objects and natural phenomena, they enhance the aesthetic impact of their perception, promote the development of entrepreneurial initiatives and creation of additional jobs. At 
this stage we can conclude that only experimental design and construction will determine the possible implementation of open high-rise structures in the environment and allow making final conclusions.

\section{References}

1. Yu. A. Barzykin, Current problems and main developmental perspectives of the Russian tour industry, Vestnik of National Tourism Academy, 2, 7-8 (2010)

2. L. D. Zhigula, Nature protected areas as a resource of ecological tourism, Vologdin recitations, 6-8 (2008)

3. K. A. Makarova, Assessment of the environmental and recreational potential of the national parks of Russia, Newsletter of North-Caucasus Federal University, 2(41), 1923 (2014)

4. A. Yu. Aleksandrova, The newest comprehension of tourism as a system, Modern challenges of service and tourism, 1, 24-38 (2014)

5. T. Ya. Vavilova, I. S. Chakina, Prospects of development of ecological tourism infrastructures in protected natural areas, Urban construction and architecture, 3(24), 97-102 (2016)

6. Samarskaya Luka: current state and sustainable development of landscape-urban complex, 376 (Samara, 1997)

7. A. V. Shabanova, Restrictions on environmental requirements arising from the development of tourism in the village of Shiryaevo (Zhiguli Pearl), Ecological challenges of the post-Soviet region: international collection of scientific articles, 117 128 (Lipetsk, 2014)

8. M. I. Balzannikov, E. G. Vyshkin, Yu. M. Galitskova, Use of hydraulic engineering structures as recreational and tourist objects, Bulletin of the Volga regional branch of the Russian Academy of Architecture and Construction Sciences, 19, 189-195 (2016)

9. T. Ya. Vavilova, I. S. Chakina, Functional design features of infrastructure objects of educational tourism for national parks. Visit centers. Collection of articles: Traditions and innovations in construction and architecture, Architecture and design, 44-48 (Samara, 2016)

10. E. Ju. Kolbovsky, Aesthetic Estimation of Landscapes: Problems of Methodology, Yaroslavl Pedagogical Bulletin, 4, 161-166 (2011)

11. T. M. Krasovskaya, Aesthetic Landscapes Functions: Methodology of assessment and preservation, Geopolitics and Ecogeodynamics of regions, 2(13), 51-55 (2014)

12. V. A. Nikolaev. Problems of landscape aesthetics, Geography, society, environment, 276-283 (2004)

13. S.Y. Grishin. Methodological foundations for sustainable development of the tourism industry, Izvestiâ Sankt-Peterburgskogo gosudarstvennogo èkonomičeskogo universiteta, 4, 7-10 (2014)

14. T. M. Krivosheeva. Tourist destination: the questions of the marketing strategy forming, Services in Russia and abroad, 6(53), 217-229 (2014)

15. D. Yu. Desyatnichenko, O. Yu. Desyatnichenko, A. D. Shmatko. Journal of Economy and entrepreneurship, 3-2(68-2), 328-332 (2016)

16. M. S. Oborin. Tourist infrastructure: social and economic analysis of the basic concepts and definitions, Scientific notes of Orel state University. Series: Humanities and social Sciences, 5, 87-93 (2014) 
17. M. Baud-Bovy, F. Lawson. Miscellaneous: Tourism and recreation: handbook of planning and design, 304 (1998)

18. J. Kleinmanns. Schau ins Land. Aussichtstürme, 152 (Marburg, Jonas-Verlag, 1999)

19. URL: http://www.npsr.qld.gov.au/recreation/pdf/development-of-outdoor-recfacility.pdf. (last accessed 21.06.2017)

20. Planning and Design of Outdoor Recreation Facilities, U. S. Army Corps of Engineers, 192 (2001)

21. URL: http://thepostcardemporium.ecrater.com/p/3336704/steel-observation-tower-inhot-springs. (last accessed 21.06.2017)

22. URL: http://art-oboz.ru/uncategorized/fotografii-sdelannye-vo-vremia-pyteshestviiageologa-arnolda-haima-po-sovetskomy-souzy.html. (last accessed 20.06.2017)

23. URL: http://americanbutler.ru/majami/sady-parki-i-zapovedniki-v-majami/park-dolinashark-valley-v-majami. (last accessed 26.06.2017)

24. URL: https://tury.club/sight/1606 (last accessed 29.06.2017)

25. URL: http://www.hotspringsar.com/info/tower/tower.htm. (last accessed 29.06.2017)

26. URL: http://www.fodors.com/world/north-america/usa/florida/the-everglades/thingsto-do/sights/reviews/observation-tower-428531 (last accessed 01.07.2017)

27. URL: http://archive.knoxnews.com/news/local/park-competes-for-grant-to-restoreclingmans-dome-tower-33ad8a45-54e2-3d18-e053-0100007ffd4f-380991721.html (last accessed 11.07.2017)

28. URL:

http://old-news.tts.lt/site/ru/V_Visaginase/19786Gorjachaja_linija_TTS_Obzornojj_bashne_da_da_da_.htm (last accessed 09.07.2017)

29. URL: https://c2.staticflickr.com/6/5474/11368480306_2e4343e288_b.jpg (last accessed 10.07.2017)

30. URL: http://cortijo-los-almendros.co.uk/things-to-do/granada/trip-parque-de-lasciencias-granada/ (last accessed 23.06.2017)

31. URL: https://gorsociety.wordpress.com/travel-numc-2012/about-glasgow/ (last accessed 24.06.2017)

32. URL: http://www.marksbarfield.com/\#/projects/brighton-i360/?null (last accessed 21.06.2017)

33. URL: http://www.balticlakes.lt/en/entertainment/panoramic-tower-rumsiskes-1783/ (last accessed 21.06.2017)

34. URL: http://ecology.md/page/nacionalnyj-park-bavarskij-les-foto (last accessed 18.06.2017)

35. http://zvejai.ltic.lt/ru/tourism-list_poi/obzornaya-bashnya-labanorskogoregionalynogo-parka/ (last accessed 03.07.2017)

36. URL: http://niagarawatch.com/portfolio/niagara-falls/ (last accessed 04.07.2017)

37. URL: http://venagid.ru/4867-pyramidenkogel/ (last accessed 21.06.2017)

38. URL:http://www.archdaily.com/24089/zaabeel-park-observation-tower-xtenarchitecture (last accessed 20.06.2017)

39. URL:http://www.amusingplanet.com/2015/12/20-most-beautiful-observationtowers.html (last accessed 19.06.2017)

40. URL: http://www.archdaily.com/787423/vlooyberg-tower-close-to-bone (last accessed 15.06.2017) 